\title{
The Ameliorating Role of Geraniol Oil on Renal Toxicity Induced by Some Pesticides in Rats
}

\author{
Gehan I. Kh. Marei
}

\begin{abstract}
The Defensive impact of geraniol (GeoH) against renal oxidative injury and nephrotoxicity induced by betacyfluthrin, ( $\beta-C y f)$, fipronil(FPN). and their combined effects on the male rats were investigated. Eight categories, each category of male rats were used contain six rats. Category I as control, Category $2 \mathrm{GeOH}(100 \mathrm{mg} / \mathrm{kg}$ bwt in corn oil). Categories 3,4 and 5 rats have presented a single daily oral dose of (FPN) fipronil $(4.85 \mathrm{mg} / \mathrm{kg} \mathrm{bwt}),(\beta-C y f)$ beta-Cyfluthrin (19 mg/kg bwt)) and their combination. Categories 6, 7 and 8 rats have presented the same doses as Categories 3, 4 and 5 with GeOH $(100 \mathrm{mg} / \mathrm{kg})$ for 28 consecutive days, respectively. Rats which was exposed insecticides compared to control recorded significant decrease in body weight and rise in kidney weight. Treatment rats recorded significant renal function disruption by increase in uric acid and serum creatinine level. Also, insecticide-treated rats revealed renal oxidative damage was spotted in insecticide-treated rats through an increase in kidney lipid peroxidation (LPO) also, kidney appeared the decrease in antioxidant enzymes. Histopathological analysis of the kidney appeared that tubular destruction with multiple vacuolations, hyaline degeneration in glomeruli, and the thick arterial wall, and irregular glomerular lining in treated groups (FPN, $\beta-C y f$, FPN $+\beta$-Cyf). In conclusion, the use of Geraniol (GeOH) seemed to be useful to rats, to a great extent by alleviation and decrease the damage sustained by insecticide exposure.

Keywords: Geraniol; fipronil; beta-cyfluthrin; nephrotoxicity; oxidative stress; histopathology
\end{abstract}

\section{INTRODUCTION}

There are many types of Pollution sources as the pesticides that contain a big group of dangerous chemicals which using for agricultural protection (Hardersen and Wratten, 1998). It is found Major target organs of pesticides are liver and kidney which causes damage and toxicity (Mansour and Mossa, 2010; Abdel Rasoul and Marei, 2016). Insecticides encourage the induction of reactive oxygen species (ROS) and causing damage to lipids, proteins, enzymes, carbohydrates and nucleic acids (Fraga et al., 1996; Kartheek and David, 2018). Cyfluthrin is a synthetic pyrethroid vastly used in agriculture against grasshoppers and pests. Cyfluthrin is also used in human hygiene (FAO, 1999). After its first use in 1987 in the USA. UU (EPA, 1987), studied its effect toxic in the environment and observed that it had genotoxic and cytotoxic effects on human lymphocytes (Ila et al., 2008), genotoxic effects on human mucosal epithelial cells (Tisch et al., 2005) and DNA injury in fish (Marinowic et al.,2012). It has been discovered mutagenic and genotoxic effects in mammals by Some pyrethroid insecticides (Herrera and Laborda, 1998; Hour et al., 1998; Shukla and Taneja, 2002; Giri et al., 2002; Cavas and Ergene-Gozukara, 2003).

Fipronil (FPN, 5-amino-1-(2,6-dichloro-4(trifluoromethylphenyl)-4-(trifluoro-methylsulfinyl)

pyrazole-3-carbonitrile) is a phenylpyrazole insecticide which is a relatively new and massively used to kill insects that cause damage to the plant crops (Mcmahen et al., 2015; Pisa et al., 2015). Around the world, FPN use to protect rice, cotton, sorghum, corn, cereals barley, oats, rye, triticale, wheat, grass, straw, and so on. FPN controls a broad spectrum of insects such as cockroaches, mosquito, lobster, termites, thrips, rootworms, ticks, and fleas in the larval and adult stages (Gunasekara et al.2007).

Although FPN showed lower toxicity in mammals than in insects, FPN was documented to have reverse effects such as the liver, thyroid, and influenced reproductive function in nontarget species (Ohi et al., 2004; Das et al., 2006; Roques et al., 2013). exposure rats to FPN led to the harm of the thyroid, liver, and kidney (Tingle et al., 2003).

recently, essential oils have been used by researchers as free radical scavengers or antioxidants. (Choi et al., 2000). Geraniol has many pharmacological effectiveness such as antimicrobial (Lorenzi et al. 2009), anticancer (Pattanayak et al. 2009), anti-lipid peroxidative (Chen and Viljoen 2010), and antioxidant (Tiwari and Kakkar 2009).

Therefore, this study aimed to evaluate the adverse effects of sub-chronic exposure to formulated FPN, $\beta$ Cyf and their combination on the oxidative damage and the renal toxicity. In addition, the efficiency of geraniol oil was studied for ameliorating harmful effect of these insecticides.

DOI: 10.21608/ASEJAIQJSAE.2019.28701

${ }^{1}$ Department of Plant Protection, Faculty of Agriculture,

Damanhour University, Damanhour 22516, Egypt.

Email: gmarei07@gmail.com.

Received February 15, 2019, Accepted March 14, 2019 


\section{MATERIALS AND METHODS}

\section{Animals}

Male Wistar rats weighing $170 \pm 5 \mathrm{~g}$ were obtained from the animal house, Faculty of Medicine, Alexandria University, Egypt. The local committee confirmed the design of the experiments and the protocol adapts to the guidelines of the National Institutes of Health (NIH). and put it in cages (6 rats / cage) in the laboratory animal at room temperature. water ad libitum every day until finish the experment, In a standard pellet diet. It has been acclimatized the rats for 1 week.

\section{Chemicals}

Geraniol (99\% pure) was purchased from Acros Organics Company, New Jersey, USA. The fipronil commercial formulation (Fipral 5\% SC) and betacyfluthrin (beta-s 10\%) were provided by Agricontact Agricultural Service Company, Alexandria, Egypt. Chemicals and kits have been obtained from Biodiagnostics Co., Dokki, Giza, Egypt. Other reagents used were of analytical grade. Solvents were of analytical grade.

\section{Experimental design}

It has been split rats into 8 groups every including 6 animals (6 rats/cage).

Category 1: Was given Corn oil and kept as a control.

Category 2: Was given $100 \mathrm{mg} / \mathrm{kg} \mathrm{GeOH}$ in corn oil $(0.5 \mathrm{ml} / \mathrm{rat})$.

Category 3: Was given $\left(1 / 20 \mathrm{LD}_{50}\right)$ (Tomlin 2005), FPN at a daily dose of $4.85 \mathrm{mg} / \mathrm{kg}$ b.wt.

Category 4: Was given (1/20 LD 50 (Tomlin 2005), $\beta$ Cyf at a daily dose of $19 \mathrm{mg} / \mathrm{kg}$ b.wt.

Category 5: Was given FPN (4.85 mg/kg b.wt.) and $\beta$ Cyf (19 mg/kg b.wt.).

Category (6- 8): Was given $100 \mathrm{mg} / \mathrm{kg} \mathrm{GeOH}$ in corn oil and the same doses of insecticides as in categories (3-5). It has been registrated the body weights for rats, during expermintal, and the doses modify according to the weight gaining weekly body. After completion of the treatment period, blood samples were centrifuged at $1500 \times \mathrm{g}$ for $10 \mathrm{~min}$ and the serum was extracted and stored at $-20{ }^{\circ} \mathrm{C}$ for biochemical measurements by using Shimadzu UV- VIS Recording 2401 PC (Japan). It has been removed, cleaned and weighed the both kidneys for histological and biochemical evaluation. Samples are kept in ice-cold buffered saline $(154 \mathrm{mM} \mathrm{NaCl}, 5 \mathrm{mM}$ Tris-HEPES (Tris- $\mathrm{HCl}$ buffers and phosphates in PBS, $\mathrm{pH}$ 7.5). It was prepared $10 \%(\mathrm{w} / \mathrm{v})$ homogenate in $0.1 \mathrm{M}$ Tris- $\mathrm{HCl}$ buffer, pH 7.5, by using homogenizer Potter-Elvehejem. It has been centrifuged the homogenate at $3000 \mathrm{x}$ g at 4 ${ }^{\circ} \mathrm{C}$ for $15 \mathrm{~min}$ and it has been saved the supernatant in aliquots and stored at $-20{ }^{\circ} \mathrm{C}$ for testing protein concentration, lipid peroxidation (LPO) and antioxidant enzymes efficiency.

\section{Measurement of biochemical parameters}

It has been estimated total protein, creatinine, and uric acid according to the methods of (Gornall et al.,1949; Larsen, 1972; Barham andTrinder, 1972; Tietz, 1995), orderly.

\section{Oxidative stress evaluation}

Thiobarbituric acid reactive substances (TBARS) content is an indicator of lipid peroxidation in the kidney homogenate was measured by (Tappel and Zalkin,1959). Reduced glutathione content (GSH), a tripeptide ( $\gamma$-glutamylcysteinyl glycine), in tissues was assayed by the method of Jollow et al. (1974) and the concentration expressed as a $\mu$ moles of GSH $/ \mathrm{mg}$ protein.

\section{Renal antioxidant enzymes:}

Catalase assay (CAT): Catalase (CAT; EC 1.11.1.6) was estimated (Aebi, 1984) by examination the hydrolysis of $\mathrm{H}_{2} \mathrm{O}_{2}$ and the resulting reduced in absorbance at $510 \mathrm{~nm}$ over a $3 \mathrm{~min}$ period at $25 \mathrm{C}^{\circ}$.

Assay of superoxide dismutase (SOD): Superoxide dismutase effectiveness (SOD; EC 1.15.1.1) was estimated (Nishikimi et al., 1972).

Assays of glutathione peroxidase (GPx): Glutathione peroxidase (GPx) efficiency was determined using $\mathrm{H} 2 \mathrm{O} 2$ as a substrate (Paglia and Valen-tine, 1987).

\section{Histopathological studies}

Histopathological has been checked according to (Bancroft et al., 1996). samples from kidney were fixed in $10 \%$ phosphate buffer formalin, dehydrated in alcohols and firmed in paraffin, and

checked by light microscopic.

\section{Statistical analysis}

The Statistical Package for Social Sciences ver. 21.0 were used. Analysis of variance (ANOVA) has been estimated by using one-way followed by Duncan's test for comparison between different treatment groups.

\section{RESULTS}

\section{Marks of toxicity}

During the experiment, it has not been detected death in any of the experimental categories. Rats in the control category and in geraniol $(\mathrm{GeOH})$ treated group did not show any mark of toxicity. But, CPF and $\mathrm{Cyr}+\mathrm{CPF}$ treated rats showed different degrees of clinical signs few minutes after dosing. The signs inclusive huddling, mild tremor and diarrhea. The 
observed marks were related to the cholinergic crisis and an abnormal walk.

\section{Body and relative kidney weights}

Result, in (Table 1) cleared that there was no significant difference in body, absolute and relative kidney weights between $\mathrm{GeOH}$ and untreated rats. However, body weight was significantly decreased by $5.27 \%, 5.9 \%$ and $7.83 \%$ for FPN, $\beta$-Cyf and FPN $+\beta$ Cyf - treated groups, respectively. Relative kidney weight significantly raised by $12.3 \%, 17.9 \%$ and $20 \%$ for FPN, $\beta$-Cyf and FPN + $\beta$-Cyf - treated groups, respectively when compared to control. The treated with $\mathrm{GeOH}$ to pesticide-treated groups ameliorated the loss of body weight and the rise of relative kidney weight in pesticide-treated animals (Table 1).

\section{Oxidative stress parameters.}

The results cleared that FPN, $\beta$-Cyf and FPN $+\beta$ Cyf gave a significant increase $(\mathrm{p}<0.05)$ in lipid peroxidation as evidenced by the increase in kidney tissue TBRAS levels by58.32, 66.62, and 74.68\%, respectively when compared to the control category. However, using $\mathrm{GeOH}$ to treated rats reduced the augmentation in TBRAS levels to $44.2,118.7$ and $196.8 \%$ for FPN, $\beta$-Cyf and FPN $+\beta$-Cyf treated rats, respectively (Fig. 1A). Glutathione (GSH), in the reduced form (GSH), acts as one of the major detoxifiers in the body. A significant decrease of glutathione (GSH) level in kidney was evident in FPN, $\beta$-Cyf and FPN $+\beta$-Cyf treated groups by $-54.8 \%$, $61.6 \%$ and $-73.3 \%$, respectively when compared to control (Fig. 1A). However, co-administration of $\mathrm{GeOH}$ to treated rats ameliorated the decrease in kidney GSH levels to $-46.2 \%,-30.5 \%$ and $-55.8 \%$ for FPN, $\beta$-Cyf and FPN $+\beta$-Cyf treated rats, respectively (Fig. 1B).

Table 1. Effect of FPN and/or $\beta$-Cyf on body and relative kidney weights of rats and the role ameliorating of geraniol

\begin{tabular}{|c|c|c|c|c|c|}
\hline \multirow[t]{2}{*}{ Groups } & \multicolumn{3}{|c|}{ Body weight } & \multirow{2}{*}{$\begin{array}{l}\text { Weight absolute } \\
\text { of kidney } \\
\text { (g) }\end{array}$} & \multirow{2}{*}{$\begin{array}{c}\text { Weight relative of } \\
\text { kidney } \\
\text { (g/100g body weight) }\end{array}$} \\
\hline & Initial (g) & Final (g) & $\%$ Change/week & & \\
\hline Control & $165.62 \pm 0.63$ & $195.57 \pm 1.92^{\mathrm{ab}}$ & $4.52 \pm 0.39^{\mathrm{a}}$ & $1.25 \pm 0.02$ & $0.64 \pm 0.01^{\mathrm{d}}$ \\
\hline $\mathrm{GeOH}$ & $168.25 \pm 0.83$ & $200 \pm 0.82^{\mathrm{a}}$ & $4.71 \pm 0.03^{\mathrm{a}}$ & $1.23 \pm 0.01$ & $0.61 \pm 0.01^{\mathrm{d}}$ \\
\hline FPN & $170 \pm 1.22$ & $185.25 \pm 1.7^{\mathrm{c}}$ & $2.78 \pm 0.36^{\mathrm{b}}$ & $1.36 \pm 0.04$ & $0.73 \pm 0.02^{\mathrm{abc}}$ \\
\hline$\beta$-Cyf & $165 \pm 0.71$ & $184 \pm 0.81^{\mathrm{cd}}$ & $2.88 \pm 0.19^{b}$ & $1.41 \pm 0.04$ & $0.78 \pm 0.02^{\mathrm{ab}}$ \\
\hline $\mathrm{FPN}+\beta-\mathrm{Cyf}$ & $173 \pm 1.22$ & $180.25 \pm 1.03^{\mathrm{d}}$ & $1.05 \pm 0.27^{\mathrm{c}}$ & $1.49 \pm 0.02$ & $0.81 \pm 0.01^{\mathrm{a}}$ \\
\hline $\mathrm{FPN}+\mathrm{GeOH}$ & $166.75 \pm 1.43$ & $197.25 \pm 0.47^{\mathrm{a}}$ & $4.58 \pm 0.32^{\mathrm{a}}$ & $1.36 \pm 0.03$ & $0.68 \pm 0.01^{\mathrm{cd}}$ \\
\hline $\mathrm{B}-\mathrm{Cyf}+\mathrm{GeOH}$ & $167.75 \pm 1.03$ & $186.25 \pm 1.03^{\mathrm{c}}$ & $2.76 \pm 0.3^{b}$ & $1.37 \pm 0.04$ & $0.73 \pm 0.02^{\mathrm{abc}}$ \\
\hline $\mathrm{FPN}+\beta-\mathrm{Cyf}+\mathrm{GeOH}$ & $173 \pm 1.22$ & $191.50 \pm 0.95^{\mathrm{b}}$ & $2.68 \pm 0.32^{\mathrm{b}}$ & $1.38 \pm 0.02$ & $0.72 \pm 0.01^{\mathrm{bc}}$ \\
\hline
\end{tabular}

$\mathrm{a}, \mathrm{b}, \mathrm{c}, \mathrm{d}$ Duncan's test, $p<0.05$

FPN: Fipronil; $\beta$-Cyf: $\beta$ - Cyfluthrin; GeoH: Geraniol

The percent of body weight change/week $=[($ final b .w t. - initial b .wt. $) /$ initial b .wt. $] /$ no of weeks X 100
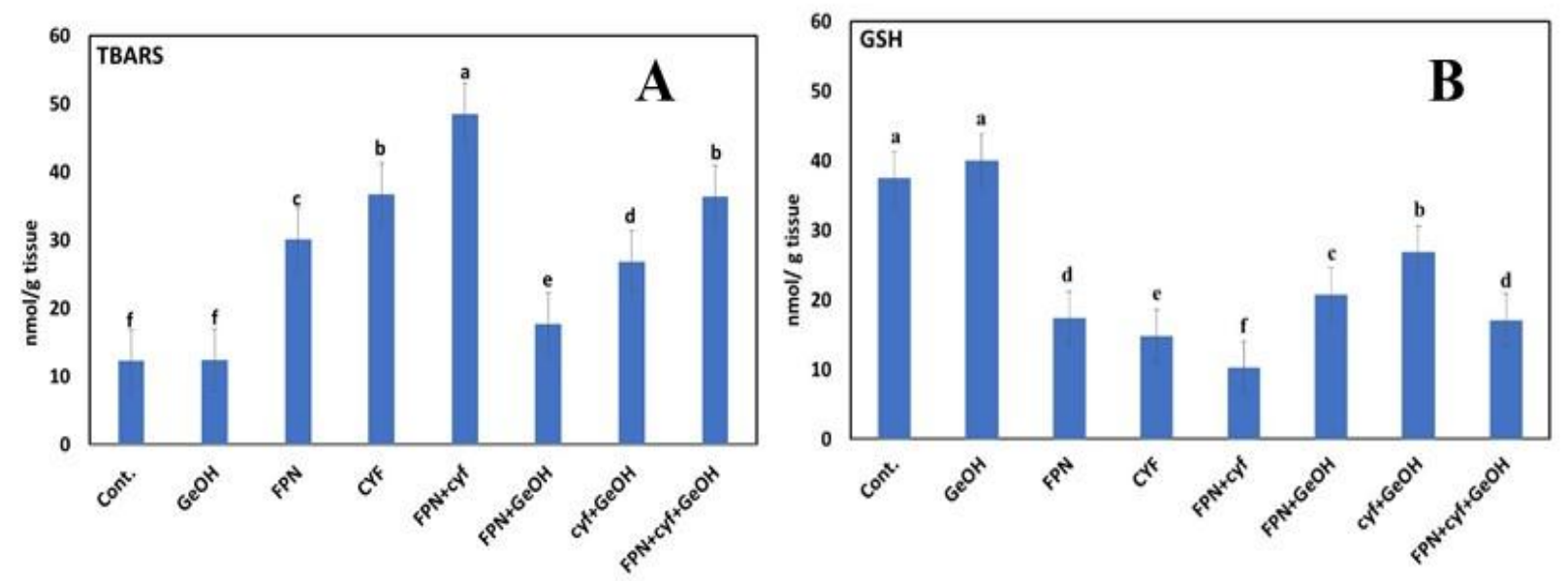

Fig.1. Effect of FPN and $\beta$-Cyf on oxidative stress by product TBARS (A) and kidney tissue GSH (B) of rat in the non-attendance and attendance of $\mathrm{GeOH}$. 


\section{Markers of renal function}

Results in Table 2 illustrated that no significant changes between the untreated control and $\mathrm{GeOH}$ treated in serum creatinine, uric acid, and total protein, while level of FPN, $\beta$-Cyf and FPN $+\beta$-Cyf treated rats were significant increase in creatinine $48.9 \%, 34.24 \%$ and 70.83 and uric acid $131.9 \%, 146.7 \%$ and $204 \%$, respectively. But reduced by $-15.3 \%,-18.15 \%$ and $23.3 \%$ in the total protein. There is amelioration in the level of Cre and uric acid due to using of $\mathrm{GeOH}$ to tested groups.

\section{Effects on activities of kidney antioxidant enzymes}

Results in Table 3 showed the effect of FPN, $\beta$-Cyf and FPN $+\beta$-Cyf treated rats on the activities of CAT, SOD, and GPx. There was damage in rats by the significant alteration in these enzymes when using subacute levels of the tested pesticides due to a state of kidney damage and extensive oxidative. $\mathrm{GeOH}$ alone has a significant variation in GPx and CAT effectiveness compared to control, while the effect of $\mathrm{GeOH}$ alone on SOD enzyme no significant difference compared to control. Also, therapy with $\mathrm{GeOH}$ had mitigated from the injury effect as it was more efficient with a significant improvement in oxidative stress markers and antioxidant enzymes.

\section{Study of histopathological}

The histopathological studies in the kidney are appeared in Figure 2 (A-I). the control category rats and $\mathrm{GeOH}$-treated rats appeared that the normal tissue and intact glomeruli. However, there were abnormalities in the kidney of treated rats in glomeruli and tubular destruction with multiple vacuolations, hyaline degeneration in glomeruli, and the thick arterial wall, and irregular glomerular lining in (Figure 2B-I) compared to those of controls (Figure 2A). The major characteristic was finding the appearance of renal tissue with hypocellular, hemorrhagic and irregular glomerular lining, arterial wall its thick, congested dilated artery, and destructed glomeruli. However, treatment of the $\mathrm{GeOH}$ with FPN or $\beta$-Cyf showed clear amelioration with the compare to (FPN, $\beta$-Cyf and FPN $+\beta$-Cyf) alone.

Table 2. Effect of FPN, $\beta$-Cyf and their incorporation on serum creatinine, uric acid and total protein of male rat in the absence and presence of GeoH

\begin{tabular}{lccc}
\hline Groups & $\begin{array}{c}\text { Creatinine } \\
\mathbf{~ m g / d L}\end{array}$ & $\begin{array}{c}\text { Uric Acid } \\
\mathbf{~ m g / d L}\end{array}$ & $\begin{array}{c}\text { TP } \\
\text { g/dL }\end{array}$ \\
\hline Control & $0.960 \pm .021^{\mathrm{d}}$ & $3.98 \pm 0.120^{\mathrm{f}}$ & $7.44 \pm 0.062^{\mathrm{a}}$ \\
$\mathrm{GeOH}$ & $0.890 \pm 0.008^{\mathrm{d}}$ & $3.71 \pm 0.057^{\mathrm{f}}$ & $7.49 \pm 0.056^{\mathrm{a}}$ \\
FPN & $1.43 \pm 0.029^{\mathrm{b}}$ & $9.23 \pm 0.176^{\mathrm{c}}$ & $6.30 \pm 0.081^{\mathrm{c}}$ \\
$\beta-\mathrm{Cyf}$ & $1.46 \pm 0.042^{\mathrm{b}}$ & $9.82 \pm 0.102^{\mathrm{b}}$ & $6.13 \pm 0.062^{\mathrm{c}}$ \\
$\mathrm{FPN}+\beta$-Cyf & $1.64 \pm 0.021^{\mathrm{a}}$ & $12.12 \pm 0.095^{\mathrm{a}}$ & $5.70 \pm 0.108^{\mathrm{d}}$ \\
FPN $+\mathrm{GeOH}$ & $1.21 \pm 0.053^{\mathrm{c}}$ & $7.17 \pm 0.081^{\mathrm{e}}$ & $6.76 \pm 0.042^{\mathrm{b}}$ \\
$\mathrm{B}-\mathrm{Cyf}+\mathrm{GeOH}$ & $1.20 \pm 0.038^{\mathrm{c}}$ & $7.58 \pm 0.077^{\mathrm{de}}$ & $6.85 \pm 0.021^{\mathrm{b}}$ \\
FPN $+\beta-\mathrm{Cyf}+\mathrm{GeOH}$ & $1.38 \pm 0.041^{\mathrm{b}}$ & $7.90 \pm 0.334^{\mathrm{d}}$ & $6.10 \pm 0.040^{\mathrm{c}}$ \\
\hline
\end{tabular}

$\mathrm{a}, \mathrm{b}, \mathrm{c}, \mathrm{d}$ Duncan's test, $p<0.05$

FPN: Fipronil; $\beta$-Cyf: $\beta$ - Cyfluthrin; GeoH: Geraniol oil

Table 3. Effect of FPN, $\beta$-Cyf and their incorporation on antioxidant enzymes in kidney tissue of male rats in the absence and presence of $\mathrm{GeOH}$

\begin{tabular}{lccc}
\hline Treatments & $\begin{array}{c}\text { SOD } \\
\text { mU/mg protein }\end{array}$ & $\begin{array}{c}\text { GPx } \\
\text { mU/mg protein }\end{array}$ & $\begin{array}{c}\text { CAT } \\
\text { U/mg protein }\end{array}$ \\
\hline Control & $47.66 \pm 0.694^{\mathrm{a}}$ & $17.88 \pm 0.411^{\mathrm{b}}$ & $24.38 \pm 0.647^{\mathrm{b}}$ \\
GeOH & $49.33 \pm 1.177^{\mathrm{a}}$ & $20.66 \pm 0.771^{\mathrm{a}}$ & $26.60 \pm 0.647^{\mathrm{a}}$ \\
FPN & $26.98 \pm 0.844^{\mathrm{c}}$ & $12.78 \pm 0.146^{\mathrm{d}}$ & $13.79 \pm 0.615^{\mathrm{c}}$ \\
$\beta-\mathrm{Cyf}$ & $23.71 \pm 0.742^{\mathrm{d}}$ & $10.75 \pm 0.236^{\mathrm{e}}$ & $10.15 \pm 0.228^{\mathrm{f}}$ \\
FPN $+\beta-\mathrm{Cyf}$ & $15.99 \pm 0.353^{\mathrm{e}}$ & $8.36 \pm 0.334^{\mathrm{f}}$ & $8.85 \pm 0.230^{\mathrm{f}}$ \\
FPN + GeOH & $37.62 \pm 0.762^{\mathrm{b}}$ & $17.24 \pm 0.516^{\mathrm{b}}$ & $19.06 \pm 0.251^{\mathrm{c}}$ \\
$\mathrm{B}-\mathrm{Cyf}+\mathrm{GeOH}$ & $36.17 \pm 0.400^{\mathrm{b}}$ & $14.71 \pm 0.285^{\mathrm{c}}$ & $17.24 \pm 0.489^{\mathrm{d}}$ \\
FPN $+\beta-\mathrm{Cyf}+\mathrm{GeOH}$ & $27.14 \pm 0.620^{\mathrm{c}}$ & $12.36 \pm 0.432^{\mathrm{d}}$ & $16.24 \pm 0.286^{\mathrm{d}}$ \\
\hline
\end{tabular}

$\mathrm{a}, \mathrm{b}, \mathrm{c}, \mathrm{d}$ Duncan's test, $p<0.05$

FPN: Fipronil; $\beta$-Cyf: $\beta$-Cyfluthrin; GeoH: Geraniol oil 

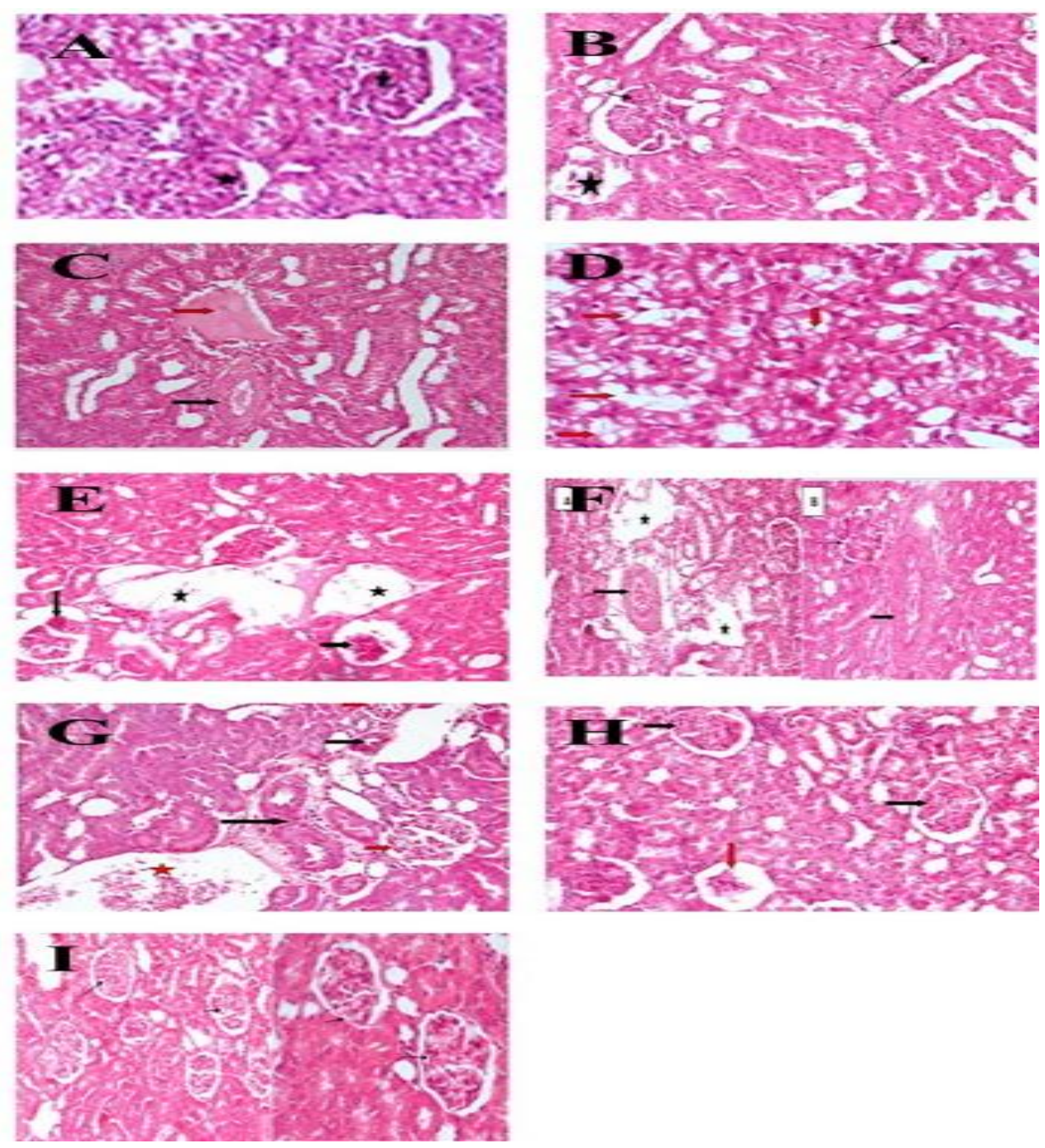

Fig. 2. A photomicrography of kidney tissue stained by haematoxylin and eosin (H\&E 200). Control category [A] showing showing normal renal tissue with normal appearing glomeruli (star), FPN-treated group [B \&C] showing renal tissue with hypocellular and hemorrhagic glomeruli (thin arrow), and one disturbed glomeruli (star) and hyaline degeneration in glomeruli (red arrow), and thick arterial wall (black arrow) $(H \& E$ 100), $\beta$-Cyf- treated group [D \&E] showing tubular destruction with multiple vacoulation (red arrow) and destructed glomeruli (star), and hypocellular glomeruli (black arrow) (H\&E 100), FPN \& $\beta$-Cyf- treated category $[F]$ showing thickened arterial wall (thick arrow), destructed glomeruli (star) and irregular glomerular lining (thin arrow) (H\&E 100), GeOH \& FPN - treated category [G] showing thickened arterial wall ( black arrow), disturbed glomeruli (star) and partially appearing normal glomeruli ( rad arrow) (H\&E $100), \mathrm{GeOH} \& \beta$-Cyf - treated group $[\mathrm{H}]$ showing three normal glomeruli (black arrow) and one disturbed glomeruli ( rad arrow) (H\&E 100), GeOH \& FPN \& $\beta$-Cyf treated category[I] showing normal glomeruliwith tiny vacoulation (arrow) (H\&E 100, 200)

\section{DISCUSSION}

Renal toxicity occurs due to pesticides exposure and environmental pollutants. This work represents the ameliorating effect of kidney function by using $\mathrm{GeOH}$ with FPN, $\beta$-Cyf or their combination of FPN and $\beta$-Cyf.
The results showed that a significant decrease in body weight perhaps due to the joint impact of cholinergic and oxidative stress. As well, the results showed the high in relative kidney weight (saafi et al., 2011; Heikal et al., 2012; Mehmet et al., 2015; Abdel Rasoul and Marei, 2016 ; Turkmen et al., 2019). 
Results showed that FPN, $\beta$-Cyf and FPN $+\beta$-Cyf treatments caused oxidative stress in the kidney of male rats. There are deranged the integrity of cellular membranes cause various kidney injuries due to thiobarbituric acid reactive substances (TBARS) content. These results consent with ( $\mathrm{Yu}$ et al., 2008; Sadowska-Woda et al. 2010; Maran et al., 2010; Khan et al. 2015; Lopez- Antia et al. 2015; Turkmen et al., 2019).

Enzymatic and non-enzymatic antioxidants work with each other to protection against oxidative cell harms by ROS according to (Iqbal et al., 1999; Romero et al., 2016). In the current study, the oral administration of FPN, $\beta$-Cyf and FPN $+\beta$-Cyf to adult male rats resulted in an increase in serum creatinine and uric acid in rats. The kidney is the main site of elimination of xenobiotics (Matos et al., 2009). The serum increase levels of uric acid and Cre work as an indicator of the diagnosis of renal failure (El-Demerdash et al., 2013; Turkmen et al., 2019). In addition, the decrease of total protein in FPN, $\beta$-Cyf and FPN $+\beta$-Cyf treated rats may be due to the kidney dysfunctions, partially because of the high of the serum enzymes (Mansour and Mossa, 2010; Heikal et al., 2012).

FPN, $\beta$-Cyf and FPN $+\beta$-Cyf treatment increased oxidative stress by modifying the enzyme activities linked with antioxidant defense mechanisms in the kidney of male rats. These pesticides reducing in the effeciency of antioxidant enzymes SOD, CAT, and GPx. according (Mansour and Mossa, 2010; El-Demerdash et al., 2013; Abdel Rasoul and Marei, 2016; Turkmen et al., 2019).

Kidney biomarkers in rats exposed to the FPN, $\beta$-Cyf and FPN $+\beta$-Cyf corroborated the histopathological lesions observed in this study, renal tissue with hypocellular, hemorrhagic, and irregular glomerular lining, arterial wall its thick, congested dilated artery, and destructed glomeruli. These changes could be due to FPN, $\beta$-Cyf and FPN $+\beta$-Cyf cause injury the various membrane components of the cell. Also, histological studies on the kidney of FPN, $\beta$-Cyf and FPN $\beta$-Cyf treated rats were similar with other studies like malathion (Bolton et al., 2000), fenitrothion (Kalender et al., 2007), chlorpyrifos (Mansour and Mossa, 2009) , methyl parathion (El-Desoky et al., 2012), abamectin (Fahmi et al., 2017) and glyphosate-based herbicide (Turkmen et al., 2019) thus, the insecticides are responsible for the damage which its occurs of histopathological changes in the kidney.

furthermore, Using $\mathrm{GeOH}$ had mitigated from the injury effect in the kidney as it was more efficient with a significant improvement in oxidative stress markers, antioxidant enzymes and the histopathological studies gave better healing (Badgujar et al., 2015b; Elguindy et al., 2018).

\section{CONCLUSION}

In this study, it can be conclude that FPN, $\beta$-Cyf and FPN $+\beta$-Cyf induced kidney injury that corroborated with the histopathological lesions. The changes in kidney functions could be due to the generation of ROS, which caused damage to the membrane and all cell components. In opposite, $\mathrm{GeOH}$ decreases oxidative damage where it has antioxidant properties thus ameliorative the structural safety of cell membrane and finally alleviates the histopathological changes as well as the biochemical disorders.

\section{ACKNOWLEDGMENTS}

For interpreting the histopathological investigations, my grateful to Dr. Noha N. Mahmoud, Department of Pathology, Medical Research Division, National Research Centre, Giza, Egypt.

\section{REFERENCES}

Abdel Rasoul, M., G.I.Kh. Marei. 2016. Potential therapeutic effect of turmeric (Curcuma longa) against adverse effects of penconazole fungicide to white rats. Int $\mathrm{J}$ of Pharmacol and Toxicol 4(2):178-186.

Aebi, H. 1984. Catalase in vitro. Methods Enzymology. 105: $121-126$. http://dx.doi.org/10.1016/S00766879(84)05016-3

Badgujar, P.C., N.N. Pawar, G.A. Chandratre, A.G. Telang and A.K. Sharma. 2015b. Fipronil induced oxidative stress in kidney and brain of mice: protective effect of vitamin $\mathrm{E}$ and vitamin C. Pestic Biochem Physiol. 118:10-18.

Bancroft, G.D., A. Stevens and D.R. Turner. 1996. Theory and practice of technique. 4th edn. New York: Churchill Livingston.

Barham, D. and P. Trinder. 1972. Analyst 97:142.http://dx.doi.org/10.1039/an9729700142

Bolton, J.T., M.A. Trush, T.M. Penning, G. Dryhurst and T.J. Monks. 2000. Role of quinones in toxicology Chem. Res Toxicol $13: 135-160$.

Cavas, T. and S. Ergene-Gozukara. 2003. Evaluation of the genotoxic potential of lambdacyhalothrin using nuclear and nucleolar biomarkers on fish cells. Mutat Res 534: 93- 99.

Chen, W., A.M. Viljoen. 2010. Geraniol-A review of a commercially important fragrance material. S Afr J Bot. 76:643-651.

Choi, H.S., H.S. Song, H. Ukeda and M. Sawamura. 2000. Radical-scavenging activities of citrus essential oils and their components: detection using 1, 1-diphenyl-2picrylhydrazyl. J of Agric and Food Chemistry. 48: 41564161 . 
Das, P.C., Y. Cao, N. Cherrington, E. Hodgson and R.L. Rose. 2006. Fipronil induces CYP isoforms and cytotoxicity in human hepatocytes. Chem Biol Interact. 164(3):200-214.

Donadio, C., A. Lucchesi, G. Tramonti and C. Bianchi. 1997. Creatinine clearance predicted from body cell mass is a good indicator of renal function Kidney. Int Suppl. 63: $166-168$

El-Demerdash, F., Y. Dewer, R. H. ElMazoudyc and A. A. Attia. 2013. Kidney antioxidant status, biochemical parameters and histopathological changes induced by methomyl in CD-1 mice. Exper and Toxicol Pathology. 65: 897-901.

El-Desoky, G., M. Abdelreheem, A. AL-Othman, Z. ALOthman, M. Mahmoud and K. Yusuf. 2012. Potential hepatoprotective effects of vitamin $\mathrm{E}$ and selenium on hepatotoxicity induced by malathion in rats. Afr $\mathbf{J}$ Pharm Pharmaco. 6: 806-813.

Elguindy, N. M., G. A. Yacout and E.F. El Azab. 2018. Amelioration of DENA-induced oxidative stress in rat kidney and brain by the essential oil of Elettaria cardamomum. Journal of Basic and Applied Sciences. 7: 299-305.

EPA. U.S. 1987. Office of Pesticides and Toxic Substances, Office of Pesticide Programs, Pesticide fact sheet: Cyfluthrin. No 164 Washington DC.

Fahmi, S. M., M. A.Y Al-Eryani and M. A.A.G. Fahd. 2017. Histopathological and biochemical effects of abamectin on kidney in male albino rats. Journal of Entomology and Zoology Studies. 5(2): 245-249.

FAO. 1999. Beta-cyfluthrin, specifications and evaluations for plant protection products. Food and Agric. Organization of theUnited Nations 1-20.

Fraga, C. G., E. Cavanagh, F. Carrasquedo, S. Lotito, F. Lucesoli and P. I. Oteiza. 1996. Antioxidant defenses and mechanisms of protection against oxygen radicals. Physiol and Bioche of the Fishes of the Amazon. Manaus $323-330$.

Giri, S., G.D. Sharma, A. Giri, S.B. Prasad. 2002. Fenvalerateinduced chromosome aberrations and sister chromatid exchanges in the bone marrowcells of mice in vivo. Mutat Res. 520:125-132.

Gornall, A.C., C.J. Bardawill and M.M. David. 1949. Determination of serum protein by means of biuret reaction. J Biol Chem. 177: 751-756.

Gunasekara, A.S., T. Truong, K.S. Goh, F. Spurlock and R.S. Tjeerdema. 2007. Environmental fate and toxicology of fipronil. J Pest Sci. 32: 189-199.

Hardersent, E. and S.D. Wratten. 1998. The effects of carbaryl exposure of the penultimate larval instars of Xathocnemis zealandica on emergence and fluctuating asymmetry. Ecotoxicology. 7: 297-304.
Heikal, T. M, A.H. Mossa, G.I.Kh. Marei and M.A. Abdel Rasoul. 2012. Cyromazine and Chlorpyrifos Induced Renal Toxicity in Rats: The Ameliorating Effects of Green Tea Extract. Environ and Analytical Toxicol. 2(5): $1-7$.

Herrera A, Laborda E (1998) Mutagenic activity in synthetic pyrethroids in Salmonella typhimurium. Mutagenesis 3: 509-514.

Hour, T.C., L, Chen and J.K. Lin. 1998. Comperative investigation on the mutagenicities of organophosphate, phthalimide, pyrethroid and carbamate insecticides by the Ames and lactam tests. Mutagenesis. 13:157-166.

Ila, H.B., M. Topaktas, E. Rencuzogullari, A. Kayraldiz, L. Donbakand and Y.K. Daglioglu. 2008. Genotoxic potential of cyfluthrin.Mutat. Res./Genet. Environ. Mutagen. 656:49-54.

Iqbal, M., U. Giri, D.K. Giri, M.S. Alam and M. Athar. 1999. Age-dependent renal accumulation of 4-hydroxy-2nonenal (HNE)-modified proteins following parenteral administration of ferric nitrilotriacetate commensurate with its differential toxicity: implications for the involvement of HNE-protein adducts in oxidative stress and carcinogenesis. Arch Biochem Biophys. 365: 101112 .

Jollow, D.J., J.R. Michell, J.G. Zampaglionic and J.R. Gillete. 1974. Bromobenzene-induced Liver necrosis: Protective role of glutathione and evidence for 3, 4-bromobenzene oxide as hepatotoxic metabolite. Pharmacology. 11: 151169.

Kalender, S., Y. Kalender, D. Durak, A. Ogutcu, M. Uzunhisarcikli, B.S. Cevrimli and M. Yildirim. 2007. Methyl parathion induced nephrotoxicity in male rats and protective role of vitamins $\mathrm{C}$ and E. Pestic. Biochem Physiol. 88: 213-218.

Kartheek, R.M. and M. David. 2018. Assessment of fipronil toxicity on wistar rats: A hepatotoxic perspective. Toxicology Reports. 5 : 448-456

Khan, S., M.H. Jan, D. Kumar and A.G. Telang. 2015. Firpronil induced spermotoxicity is associated with oxidative stress, DNA damage and apoptosis in male rats. Pest Biochem Physiol. 124: 8-14.

Larsen, K. 1972. Clin. Acta. 41, 209. http://dx.doi.org/10.1016/0009-8981(72)90513-X

Lopez-Antia, A., M.E. Ortiz-Santaliestra, P.R. Camarero, F. Mougeot and R. Mateo. 2015. Assessing the risk of fipronil-treated seed ingestion and associated adverse effects in the red-legged partridge. Environ Sci Technol. 49:13649-13657.

Lorenzi, V., A. Muselli, A.F. Bernardini, L. Berti, J.M. Pages and L. Amaral. 2009. Geraniol restores antibiotic activities against multidrug-resistant isolates from Gramnegative species. Antimicrob Agents Chemother.53:2209-2211.

Mansour, S.A. and A.H. Mossa. 2010. Adverse effects of lactational exposure tochlorpyrifos in suckling rats. Hum. Exper Toxicol. 29: 77-92. 
Mansour, S.A. and A.H. Mossa. 2009. Lipid peroxidation and oxidative stress in rat erythrocytes induced by chlorpyrifos and the protective effect of zinc. Pest Biochem Physiol. 93:34-39.

Maran, E., M. Fernandez-Franzon, G. Font and M.J. Ruiz. 2010. Effects of aldicarb and propoxur on cytotoxicity and lipid peroxidation in CHO-K1 cells. Food and Chemical Toxicol. 48:1592-6.

Marinowic, D.R., M. Mergener, T.A. Pollo, S.W. Maluf and L.B. da Silva. 2012. In vivo genotoxicity of the pyrethroid pesticide beta-cyfluthrin using the comet assay in the fish Bryconamericus iheringii. Z Naturforsch $\mathrm{C}$. 67:308-311.

Matos, R.C., C. Vieira, S. Morais, M. de Lourdes Pereira and J.P. de Jesus. 2009. Nephrotoxicity of CCA-treated wood: A comparative study with $\mathrm{As}(2) \mathrm{O}(5)$ and $\mathrm{CrO}(3)$ on mice. Environ. Toxic Pharmac. 27: 259-263.

McMahen, R.L., M.J. Strynar, S. Dagnino, D.W. Herr, V.C. Moser, S. Garantziotis, E.M. Andersen, D.L. Freeborn, L. McMillan and A.B. Lindstrom. 2015. Identification of fipronil metabolites by time-of-flight mass spectrometry for application in a human exposure study. Environ Int. 78: 16-23.

Mehmet, Y., E. Rencuzogullari and M. Canli. 2015. The effects of cyfluthrin on some biomarkers in the liver and kidney of Wistar rats. Environ. Sci and Pollution Res. 22(6):4747-4752.

Nishikimi. M., N.A. Rao and K. Yog. 1972. Colormetric determination of superoxide dismutase activity.Biochem.Biophys. Res Commun. 46: 849-851. http://dx.doi.org/10.1016/S0006-291X(72)80218-3.

Ohi, M., P.R. Dalsenter, A.J. Andrade and A. J. Nascimento. 2004. Reproductive adverse effects of fipronil in Wistar rats. Toxicol Lett. 146: 121-127.

Paglia, D.E. and W.N. Valentine. 1987. Studies on the quantitative and qualitative characterization of glutathione peroxidase. J Lab Clin Med. 70: 158-165.

Pattanayak, S.P., P. Sunita and S. Jha. 2009. In vivo antitussive activity of Coccinia grandis against irritant aerosol and sulfur dioxide-induced cough model in rodents. J Pharmacol. 1:157-161.

Pisa, L.W., V. Amaral-Rogers, L.P. Belzunces, J.M. Bonmatin, C.A. Downs, D. Goulson, D.P. Kreutzweiser, C. Krupke, M. Liess, M. McField. 2015. Effects of neonicotinoids and fipronil on non-target invertebrates. Environ Sci Pollut Res Int. 22: 68-102.

Romero, A., E. Ramos, I. Ares, V. Castellano, M. Mart ınez, M.R. Mart_nez-Larra naga, A. Anadon and M.A. Mart_nez. 2016. Fipronil sulfone induced higher cytotoxicity than fipronil in SH-SY5Y cells: protection by antioxidants. Toxicol Lett. 252: 42-49.
Roques, B.B., J. Leghait, M.Z. Lacroix, F. Lasserre, T. Pineau, C. Viguie and P.G. Martin. 2013. The nuclear receptors pregnane $\mathrm{X}$ receptor and constitutive androstane receptor contribute to the impact of fipronil on hepatic gene expression linked to thyroid hormone metabolism. Biochem Pharmacol. 86: 997-1039.

Saafi, E.B., M. Louedi, A. Elfeki, A. Zakhama and M.F. Najjar. 2011. Protective effect of date palm fruit extract (Phoenix dactylifera L.) on dimethoate induced oxidative stress in rat liver. Exp Toxico Pathol. 63: 433-441.

Sadowska-Woda, I., N. Wójcik, A. Karowicz-Bilińska and E. Bieszczad- Bedrejczuk. 2010. Effect of selected antioxidants in betacyfluthrin-induced oxidative stress in human erythrocytes in vitro. Toxicol in Vitro. 24:879884.

Shukla, Y. and P. Taneja. 2002. Mutagenic potential of cypermethrin in mouse dominant lethal assay. J. Environ. Pathol Toxicol Oncol. 21:259-265.

Tappel, A.L. and H. Zalkin. 1959. Inhibition of lipid peroxidation in mitochondria by vitamin E, Archives of Biochem and Biophys. 80: 333-336.

Tietz, N.W. 1995. Clinical Guide to laboratory Tests. 3rd ed. Phila-delphia: WB Saunders 268-273.

Tingle, C.C., J.A. Rother, C.F. Dewhurst, S. Lauer and W.J. King. 2003. Fipronil: environmental fate, ecotoxicology, and human health concerns. RevEnviron. Contam Toxicol. 176: 1-66.

Tisch, M., M.K. Faulde and H. Maier. 2005. Genotoxic effects of pentachlorophenol, lindane, transfluthrin, cyfluthrin, and natural pyrethrum on human mucosal cells of the inferior and middle nasal conchae. Am J Rhinol. 19: $141-151$.

Tiwari, M. and P. Kakkar. 2009. Plant derived antioxidants geraniol and camphene protect rat alveolar macrophages against t-BHP induced oxidative stress. Toxicol in Vitro. 23:295-301.

Tiwari, M. and P. Kakkar. 2009. Plant derived antioxidantsgeraniol and camphene protect rat alveolar macrophages against t-BHP induced oxidative stress. Toxicol in Vitro. 23: 295-301.

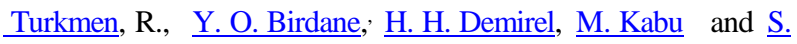
Ince. 2019. Protective effects of resveratrol on biomarkers of oxidative stress, biochemical and histopathological changes induced by sub-chronic oral glyphosate-based herbicide in rats. Toxicology research. 8 (2): 238-245.

Yu, M., S.M. Li, X.Y. Li, B.J. Zhang and J.J. Wang. 2008. Acute effects of 1-octyl-3-methylimidazolium bromide ionic liquid on the antioxidant enzyme system of mouse liver. Ecotoxicol Environ Saf. 71: 903-908. 


\section{الملخص العربي}

\section{الدور التحسيني للجيرانيول على السمية الكلوية الناجمة عن بعض المبيدات في الفئران}

$$
\text { جيهان ابراهيم خليل مرعى }
$$

الكلى بزيادة في حمض اليوريك ومستوى كرياتينين المصل. أيضا، أظهرت الفئران المعالجة بمبيدات الحشرات أن فئن الأضرار المؤكسة الكلوية شوهدت في الفئران المعالجة بمبيدات الحشرات من خلال زيادة في بيروكسيد الدهون في الكلى (LPO) أيضا، ظهرت الكلى انخفاض في الإنزيمات المضادة للأكسدة. كانالاز (CAT) ، ديسموتاز الفائق (LOD) وجلوتاثيون بيروكسيداز ظهر التحليل النسيجي (GPx) المرضي للكلية هذا التدمير الأنبوبي مع عدة فجوات، انحلال هيلي في الكبيبات، وجدار الثرايين السميك، وبطانة الكبيبات

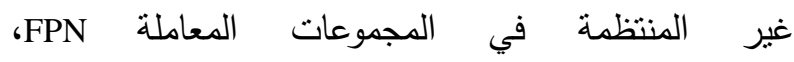
FPN + $\beta$-Cyf). في الختام، يبدو أن استخدام مفيد للفئران، إلى حد كبير عن طريق التخفيف وتقليل الضرر الذي لحق من التعرض بالمبيدات الحشرية.
الهدف من هذه الدراسة، دراسة التأثير المعالج لـ Geraniol ضد التلف التأكسدي الكلوي والتسمم الكلوي الناجم

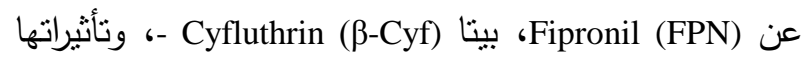
المشتركة على ذكور الفئران. يشمل البحث ثماني مجموعات من الفئران المعاملة، كل مجموعة تحتوي على ستة جرذان.

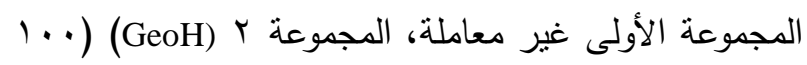
ملغم / كغم من وزن الجسم من زيت الذرة). وقد تمت معالجة الجرذان ب و ـ و وه جرعات يومية عن طريق الفم من FPN

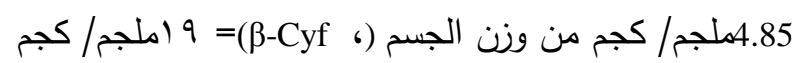

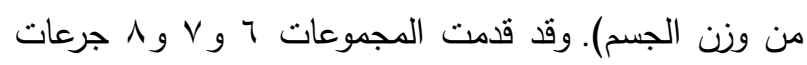
نفس الجرعات منل المجموعات ب و ع ع و 0 مع GeOH 100ملجم / كجم) لمدة ^ر يوما منتالية، على التوالي. سجلت الفئران التي تعرضت للمبيدات الحشرية مقارنة بالكونترول انخفاضًا ملحوظًا في وزن الجسم وارتفاعًا في وزن الكلى. الفئران المعاملة سجلت اضطراب كبير في وظيفة 